\title{
BLOOD CHEMISTRY OF NORMAL FULL-TERM INFANTS IN THE FIRST 48 HOURS OF LIFE
}

\author{
BY \\ P. T. ACHARYA and W. W. PAYNE \\ From the Department of Pathology, Queen Charlotte's Maternity Hospital, London
}

(RECEIVED FOR PUBLICATION DECEMBER 4, 1964)

The intention was to study the changes in the composition of the blood in the newborn infant during the first 48 hours of life by taking capillary blood samples from the heel at frequent intervals and using a development of Sanz's (1957) ultramicrotechnique for the analysis.

\section{Material and Methods}

The subjects of the study were normal infants born in hospital of healthy mothers by normal delivery. The cord was clamped at once after birth. In a subsequent paper the effects of various abnormalities of birth are examined. Sodium and potassium were estimated by flame photometer in a dilution of 10 micro litres $(\mu 1$.$) in$ $5 \mathrm{ml}$. water; chloride by iodometric titration using silver iodate; calcium by adapting Wilkinson's EDTA titration method (1957) for $20 \mu \mathrm{l}$. serum; total protein by biuret using Natelson's (1957) technique; urea by a urease method modified from Archer and Robb (1925); sugar by a modification of Nelson-Somogy's (Natelson) using $10 \mu \mathrm{l}$; inorganic phosphorus by an adaptation of Natelson's method; and lactic acid by adapting Barker and Summerson's (1941) method using $10 \mu \mathrm{l}$. serum. Haematocrit was estimated by using thin even bore heparinized capillary tubes. Cell potassium was estimated by taking $10 \mu \mathrm{l}$. whole freshly mixed blood in $5 \mathrm{ml}$. water, centrifuging, and estimating in the flame photometer.

The blood was taken from a heel using the technique described by Wilkinson (1960), but first covering the skin with sterile petroleum jelly and collecting in plastic tubing with a sealed end and a diagonally cut top containing $10 \mu 1$. of a heparin solution. Blood for sugar, phosphorus, and lactic acid was collected separately in a small tube containing fluoride and oxalate. A total of about $1 \mathrm{ml}$. was collected at $1,2,3,5,7,9,11,19,24,36$, and 48 hours after birth. Cord blood was collected at birth from the umbilical vein. All estimations were performed in duplicate.

The results are shown in detail in a Ph.D. thesis by one of us (P.T.A.) accepted by the University of London (1962) and are here summarized.

Standard deviations have been calculated on the unjustified assumption of a normal distribution in all cases.

\section{Results}

Plasma Potassium. Table 1 shows the mean and the range. It will be seen that the cord blood has a high value, $7 \cdot 79 \mathrm{mEq} / 1$., falling quickly at 1 hour and then slowly for the next 48 hours with a slight secondary peak at 3 hours. The most probable reason for the high cord value is the acute acidosis caused at birth by transient anoxia (James, 1960).

TABLE 1

PLASMA POTASSIUM CONCENTRATION (mEq/l.) OF NORMAL FULL-TERM INFANTS (PRESENT SERIES)

\begin{tabular}{c|c|c|c|c}
\hline $\begin{array}{c}\text { Hours } \\
\text { After } \\
\text { Birth }\end{array}$ & Mean & Range & SD & $\begin{array}{c}\text { No. of } \\
\text { Determi- } \\
\text { nations }\end{array}$ \\
\hline Cord & $\mathbf{7 \cdot 7 9}$ & $5 \cdot 6-12 \cdot 0$ & $\pm 2 \cdot 0$ & 14 \\
1 & $6 \cdot 78$ & $5 \cdot 3-7 \cdot 8$ & $\pm 0 \cdot 71$ & 13 \\
2 & $6 \cdot 65$ & $5 \cdot 2-8 \cdot 4$ & $\pm 0 \cdot 83$ & 13 \\
3 & $7 \cdot 0$ & $5 \cdot 7-9 \cdot 7$ & $\pm 0 \cdot 94$ & 13 \\
5 & $\mathbf{6 \cdot 8 4}$ & $5 \cdot 1-7 \cdot 5$ & $\pm 0 \cdot 73$ & 11 \\
7 & $6 \cdot 4$ & $5 \cdot 3-7 \cdot 3$ & $\pm 0 \cdot 64$ & 12 \\
9 & $6 \cdot 71$ & $5 \cdot 3-8 \cdot 0$ & $\pm 0 \cdot 79$ & 13 \\
11 & $6 \cdot 6$ & $5 \cdot 3-7 \cdot 9$ & $\pm 0 \cdot 79$ & 13 \\
18 & $6 \cdot 33$ & $5 \cdot 3-8 \cdot 9$ & $\pm 0 \cdot 78$ & 13 \\
24 & $6 \cdot 19$ & $5 \cdot 3-7 \cdot 7$ & $\pm 0 \cdot 73$ & 14 \\
36 & $6 \cdot 03$ & $5 \cdot 2-7 \cdot 3$ & $\pm 0 \cdot 63$ & 14 \\
48 & $5 \cdot 92$ & $5 \cdot 0-7 \cdot 7$ & $\pm 0 \cdot 8$ & 14 \\
\hline
\end{tabular}

This causes an exchange transfer of $\mathrm{H}^{+}$ions from plasma with $\mathrm{K}^{+}$ions of the intracellular fluid of the RBC. Other writers have found levels in the cord blood both higher than ours, e.g. Widdowson and McCance (1956) 8.0 mg., Oliver, Demis, and Bates (1961) $9 \cdot 1 \mathrm{mg}$.; and lower, e.g. Earle, Bakwin, and Hirsch (1951) 4.98 mg., Oberman, Gregory, Burke, Ross, and Rice (1956) $5.0 \mathrm{mg}$., and Österlund (1955) $5 \cdot 1 \mathrm{mg}$. Only a few reports exist for the values during the next 48 hours, Overman, Etteldorf, Bass, and Horn (1951) found lower values. Pincus Gittleman, Saito, and Sobel (1956), in the first day of life, found values a little lower $(5.4 \mathrm{mg}$.) and Usher (1959) 12-60 hour period found a mean of 6.01 ; Oliver et al. (1961) report a mean at 1 hour of $8.0 \mathrm{mg}$. and show a fall from the mean cord blood of $1.1 \mathrm{mg}$., compared with 1.0 in our series. 
Red Cell Potassium. In only three normal infants was the RBC potassium estimated (Table 2), but the values show a fairly well-marked inverse relation to the changes in the level of the plasma potassium, suggesting that the changes are at least partly due to transfer to and from the cell to the plasma (these estimations were made following a discussion of the work with Professor R. A. McCance).

TABLE 2

RED CELL POTASSIUM CONCENTRATION (mEq/1.) OF FULL-TERM NORMAL INFANTS (PRESENT SERIES)

\begin{tabular}{c|c|c|c}
\hline $\begin{array}{c}\text { Hours } \\
\text { After } \\
\text { Birth }\end{array}$ & Mean & Range & $\begin{array}{c}\text { No. of } \\
\text { Determi- } \\
\text { nations }\end{array}$ \\
\hline Cord & $99 \cdot 6$ & $97 \cdot 0-102 \cdot 0$ & 3 \\
1 & $103 \cdot 0$ & $97 \cdot 0-109 \cdot 0$ & 3 \\
3 & $100 \cdot 3$ & $99 \cdot 0-101 \cdot 0$ & 3 \\
5 & $103 \cdot 6$ & $103 \cdot 0-105 \cdot 0$ & 3 \\
7 & $106 \cdot 0$ & $100-112 \cdot 0$ & 3 \\
12 & $100 \cdot 3$ & $100 \cdot 0-102 \cdot 0$ & 3 \\
18 & $102 \cdot 6$ & $101 \cdot 0-104 \cdot 0$ & 3 \\
24 & $105 \cdot 0$ & $100 \cdot 0-108 \cdot 0$ & 3 \\
36 & $108 \cdot 3$ & $101 \cdot 0-112 \cdot 0$ & 3 \\
48 & $107 \cdot 0$ & $100 \cdot 0-114 \cdot 0$ & 3 \\
\hline
\end{tabular}

Plasma Sodium. It will be seen from Table 3 that the mean cord plasma sodium is slightly higher than the mean adult level. There is a fall in the sodium occurring in nearly all subjects during the first 12 hours, which is shown in the mean value as occurring

TABLE 3

PLASMA SODIUM CONCENTRATION (mEq/1.) OF FULL-TERM NORMAL INFANTS (PRESENT SERIES)

\begin{tabular}{c|l|l|c|c}
\hline $\begin{array}{c}\text { Hours } \\
\text { After } \\
\text { Birth }\end{array}$ & Mean & Range & SD & $\begin{array}{c}\text { No. of } \\
\text { Determi- } \\
\text { nations }\end{array}$ \\
\hline Cord & $146 \cdot 78$ & $126 \cdot 0-166 \cdot 0$ & $\pm 8 \cdot 1$ & 14 \\
1 & $145 \cdot 38$ & $122 \cdot 0-153 \cdot 0$ & $\pm 8 \cdot 23$ & 13 \\
2 & $145 \cdot 5$ & $121 \cdot 0-155 \cdot 0$ & $\pm 8 \cdot 42$ & 14 \\
3 & $142 \cdot 0$ & $109 \cdot 0-159 \cdot 0$ & $\pm 10 \cdot 4$ & 14 \\
5 & $143 \cdot 57$ & $124 \cdot 0-156 \cdot 0$ & $\pm 7 \cdot 2$ & 14 \\
7 & $143 \cdot 49$ & $130 \cdot 0-153 \cdot 0$ & $\pm 5 \cdot 8$ & 14 \\
9 & $144 \cdot 93$ & $130 \cdot 0-159 \cdot 0$ & $\pm 4 \cdot 1$ & 14 \\
11 & $146 \cdot 2$ & $132 \cdot 0-159 \cdot 0$ & $\pm 5 \cdot 6$ & 14 \\
18 & $145 \cdot 5$ & $132 \cdot 0-159 \cdot 0$ & $\pm 7 \cdot 3$ & 14 \\
24 & $146 \cdot 42$ & $131 \cdot 0-156 \cdot 0$ & $\pm 6 \cdot 5$ & 14 \\
36 & $147 \cdot 78$ & $134 \cdot 0-160 \cdot 0$ & \pm 6.9 & 14 \\
48 & $148 \cdot 7$ & $139 \cdot 0-162 \cdot 0$ & $\pm 4 \cdot 3$ & 14 \\
\hline
\end{tabular}

at 3 hours. This fall can be quite large-in one individual being as much as $31 \mathrm{mEq}$. After the fall the sodium level steadily rises to a level higher than the initial cord sodium. The results of other authors for cord blood vary: Overman et al. (1951) 134, Österlund (1955) 140, Widdowson and McCance (1956) 138, Oliver et al., $139 \mathrm{mEq} / \mathrm{l}$. Oliver et al. also estimated sodium at 1 hour and found a fall to
$134 \mathrm{mEq} / \mathrm{l}$. This fall cannot be due to loss of sodium in the urine, which is quite small during the first few hours of life, and the subsequent rise equally is not due to feeding, as in this series the policy was to give very little fluid in the first 24 hours and only a small increase in the second day. This increase in sodium has been attributed to loss of water which, if not replaced, leads to a degree of dehydration and an all round increase in the concentration of the blood constituents (Smith, 1959). The fall may be due to a transient fall in the circulating mineralo-corticoids or aldosterone, causing a temporary transfer of plasma sodium to the intracellular fluid.

Plasma Chloride. The changes in the chloride level are small and seem to bear no relation to the changes in the sodium level (Table 4), though large individual differences exist as shown by the wide range. Inspection of the individual curves shows that in the main there is not a great amount of variation during the whole 48 hours. Other authors' levels for cord blood are Overman et al., 109, Österlund (1955) 97, Widdowson and McCance, 110, Kaiser and Goodlin (1958) 104, Oliver et al. (1961) $107 \mathrm{mEq} / \mathrm{l}$.

TABLE 4

PLASMA CHLORIDE CONCENTRATION (mEg/1) OF FULL-TERM NORMAL INFANTS (PRESENT SERIES)

\begin{tabular}{|c|c|c|c|c|}
\hline $\begin{array}{l}\text { Hours } \\
\text { After } \\
\text { Birth }\end{array}$ & Mean & Range & SD & $\begin{array}{c}\text { No. of } \\
\text { Determi- } \\
\text { nations }\end{array}$ \\
\hline $\begin{array}{c}\text { Cord } \\
1 \\
2 \\
3 \\
5 \\
7 \\
9 \\
11 \\
18 \\
24 \\
36 \\
48\end{array}$ & $\begin{array}{c}103 \cdot 28 \\
102 \cdot 53 \\
98 \cdot 3 \\
101 \cdot 07 \\
100 \cdot 71 \\
104 \cdot 3 \\
101 \cdot 56 \\
102 \cdot 46 \\
103 \cdot 46 \\
105 \cdot 57 \\
102 \cdot 43 \\
102 \cdot 78\end{array}$ & $\begin{array}{l}98 \cdot 0-110 \cdot 0 \\
90 \cdot 0-110 \cdot 0 \\
81 \cdot 0-106 \cdot 0 \\
83 \cdot 0-114 \cdot 0 \\
90 \cdot 0-111 \cdot 0 \\
94 \cdot 0-117 \cdot 0 \\
83 \cdot 0-115 \cdot 0 \\
82 \cdot 0-114 \cdot 0 \\
87 \cdot 0-114 \cdot 0 \\
98 \cdot 0-119 \cdot 0 \\
92 \cdot 0-114 \cdot 0 \\
93 \cdot 0-112 \cdot 0\end{array}$ & $\begin{array}{l} \pm 4 \cdot 63 \\
\pm \mathbf{5} \cdot 68 \\
\pm 7.5 \\
\pm 7.0 \\
\pm 5.19 \\
\pm 6.1 \\
\pm 7.41 \\
\pm 7.34 \\
\pm 7.28 \\
\pm \mathbf{6} \cdot 1 \\
\pm \mathbf{7} \cdot 24 \\
\pm \mathbf{7} \cdot 14\end{array}$ & $\begin{array}{l}14 \\
13 \\
13 \\
13 \\
13 \\
13 \\
13 \\
14 \\
14 \\
13 \\
13 \\
14 \\
14 \\
14\end{array}$ \\
\hline
\end{tabular}

Blood Inorganic Phosphate. The blood phosphorus level is higher in infants and growing children than in adults (Table 5). There is a small rise in phosphate level during the first few hours of life-possibly due to the utilization of glycogen and the liberation of the phosphate bound with glycogen in its initial formation. The later fall in phosphate is paralleled by a similar fall in calcium and may be due to deposition of calcium phosphate in the bones, but there are many factors causing variation in the phosphate level.

Blood Urea. The initial cord blood urea is largely determined by the maternal level. It will be 
TABLE 5

BLOOD INORGANIC PHOSPHORUS CONCENTRATION (mg./100 ml.) OF FULL-TERM NORMAL INFANTS (PRESENT SERIES)

\begin{tabular}{|c|c|c|c|c|}
\hline $\begin{array}{l}\text { Hours } \\
\text { After } \\
\text { Birth }\end{array}$ & Mean & Range & SD & $\begin{array}{c}\text { No. of } \\
\text { Determi- } \\
\text { nations }\end{array}$ \\
\hline $\begin{array}{c}\text { Cord } \\
1 \\
2 \\
3 \\
5 \\
7 \\
9 \\
11 \\
18 \\
24 \\
36 \\
48\end{array}$ & $\begin{array}{l}5 \cdot 65 \\
6 \cdot 05 \\
6 \cdot 29 \\
6 \cdot 35 \\
6 \cdot 1 \\
5 \cdot 91 \\
5 \cdot 73 \\
5 \cdot 68 \\
5 \cdot 74 \\
5 \cdot 71 \\
5 \cdot 93 \\
5 \cdot 84\end{array}$ & $\begin{array}{l}3 \cdot 7-8 \cdot 1 \\
3 \cdot 8-9 \cdot 4 \\
4 \cdot 0-8 \cdot 2 \\
3 \cdot 7-9 \cdot 0 \\
3 \cdot 5-8 \cdot 6 \\
3 \cdot 4-8 \cdot 4 \\
2 \cdot 8-7 \cdot 8 \\
2 \cdot 9-8 \cdot 0 \\
2 \cdot 9-8 \cdot 1 \\
3 \cdot 0-8 \cdot 4 \\
3 \cdot 0-8 \cdot 7 \\
2 \cdot 8-7 \cdot 6\end{array}$ & $\begin{array}{l} \pm 1.28 \\
\pm 1.5 \\
\pm 1.42 \\
\pm 1.47 \\
\pm 1.57 \\
\pm 1.48 \\
\pm 1.53 \\
\pm 1.51 \\
\pm 1.64 \\
\pm 1.61 \\
\pm 1.6 \\
\pm 1.57\end{array}$ & $\begin{array}{l}14 \\
14 \\
14 \\
14 \\
14 \\
14 \\
14 \\
14 \\
14 \\
14 \\
14 \\
14 \\
14\end{array}$ \\
\hline
\end{tabular}

seen that the mean value falls during the first few hours of life and then slowly rises and finally stabilizes as the kidney begins to function (Table 6). The initial fall can be quite large in some subjects, up to $25 \mathrm{mg} . / 100 \mathrm{ml}$. This cannot be explained by urinary secretion as this is almost nil during the first hours of life. It is probably due to utilization of urea for enzyme protein formation (Giordano, 1963; Houpt, 1963). The later rise is due to metabolism of tissue protein. The late rise in blood urea is recorded by McCance and Widdowson (1947, 1954, 1955). No record has been found of the initial fall.

TABLE 6

BLOOD UREA CONCENTRATION (mg./100 ml.) OF FULL-TERM NORMAL INFANTS (PRESENT SERIES)

\begin{tabular}{c|c|c|c|c}
\hline $\begin{array}{c}\text { Hours } \\
\text { After } \\
\text { Birth }\end{array}$ & Mean & Range & SD & $\begin{array}{c}\text { No. of } \\
\text { Determi- } \\
\text { nations }\end{array}$ \\
\hline Cord & $29 \cdot 37$ & $21 \cdot 0-40 \cdot 0$ & $\pm 7 \cdot 3$ & 13 \\
1 & $29 \cdot 71$ & $18 \cdot 0-62 \cdot 0$ & $\pm 10 \cdot 4$ & 12 \\
2 & $24 \cdot 3$ & $6 \cdot 0-36 \cdot 0$ & $\pm 8 \cdot 1$ & 13 \\
3 & $25 \cdot 7$ & $7 \cdot 0-41 \cdot 0$ & $\pm 9 \cdot 3$ & 13 \\
5 & 27.45 & $8 \cdot 0-34 \cdot 0$ & $\pm 6 \cdot 6$ & 13 \\
7 & 27.6 & $5 \cdot 0-41 \cdot 0$ & $\pm 9 \cdot 7$ & 13 \\
9 & $28 \cdot 52$ & $6 \cdot 0-58 \cdot 0$ & $\pm 12 \cdot 2$ & 13 \\
11 & $32 \cdot 29$ & $8 \cdot 0-63 \cdot 0$ & \pm 11.8 & 13 \\
18 & $33 \cdot 45$ & $9 \cdot 0-63 \cdot 0$ & \pm \pm 11.9 & 13 \\
24 & $31 \cdot 84$ & $7 \cdot 0-69 \cdot 0$ & $\pm 12 \cdot 9$ & 13 \\
36 & $32 \cdot 53$ & $13 \cdot 0-77 \cdot 0$ & $\pm 14 \cdot 0$ & 13 \\
48 & 30.76 & $13 \cdot 0-68 \cdot 0$ & \pm 12.9 & 13 \\
\hline
\end{tabular}

Blood Sugar. The value of the blood sugar depends to some extent on the method of estimation. The method used here was for so-called 'true sugar', but it gives a higher result than the more specific glucose oxidase method by an average of $10 \mathrm{mg}$./100 $\mathrm{ml}$. The difference represents other reducing sugars. The results show a level that is low by adult standards (Table 7). There is also a wide range, the lowest value being $29 \mathrm{mg}$. at 24 hours. There are also several high values, the highest being $144 \mathrm{mg}$. at 11 hours. These high values are sharp peaks and not a
TABLE 7

BLOOD SUGAR CONCENTRATION (mg./100 ml.) OF FULL-TERM NORMAL INFANTS (PRESENT SERIES)

\begin{tabular}{c|c|c|c|c}
\hline $\begin{array}{c}\text { Hours } \\
\text { After } \\
\text { Birth }\end{array}$ & Mean & Range & SD & $\begin{array}{c}\text { No. of } \\
\text { Determi- } \\
\text { nations }\end{array}$ \\
\hline Cord & $73 \cdot 0$ & $45 \cdot 0-96 \cdot 0$ & $\pm 16 \cdot 9$ & 14 \\
1 & $62 \cdot 64$ & $31 \cdot 0-108 \cdot 0$ & $\pm 20 \cdot 1$ & 14 \\
2 & $58 \cdot 92$ & $31 \cdot 0-93 \cdot 0$ & $\pm 19 \cdot 0$ & 14 \\
3 & $63 \cdot 78$ & $39 \cdot 0-112 \cdot 0$ & $\pm 20 \cdot 1$ & 14 \\
5 & $63 \cdot 0$ & $40 \cdot 0-97 \cdot 0$ & $\pm 22 \cdot 0$ & 14 \\
7 & $59 \cdot 57$ & $35 \cdot 0-88 \cdot 0$ & \pm 20.0 & 14 \\
9 & $59 \cdot 0$ & $33 \cdot 0-88 \cdot 0$ & $\pm 14 \cdot 0$ & 14 \\
11 & $65 \cdot 14$ & $42 \cdot 0-144 \cdot 0$ & $\pm 26 \cdot 6$ & 14 \\
18 & $63 \cdot 0$ & $42 \cdot 0-104 \cdot 0$ & $\pm 16 \cdot 9$ & 14 \\
24 & $57 \cdot 85$ & $29 \cdot 0-78 \cdot 0$ & $\pm 13 \cdot 9$ & 14 \\
36 & $56 \cdot 5$ & $30 \cdot 0-91 \cdot 0$ & \pm 16.9 & 14 \\
48 & $59 \cdot 13$ & $40 \cdot 0-90 \cdot 0$ & $\pm 13 \cdot 5$ & 14 \\
\hline
\end{tabular}

prolonged rise. There is a tendency for the blood sugar to fall often to quite low levels $(30-40 \mathrm{mg}$.) during the 2-7 hours, with a final stabilizing between 50 and $60 \mathrm{mg}$. in the second day of life. These results are closely similar to those of Pederson (1952) and Farquhar (1954).

Lactic Acid. The high value in the cord blood is caused by two factors: the maternal blood lactate level is raised during labour and thus accounts for part of the increase (Table 8). The period of anoxia at birth accounts for the balance. As soon as the

TABLE 8

BLOOD LACTIC ACID CONCENTRATION (mg./100 ml.) OF FULL-TERM NORMAL INFANTS (PRESENT SERIES)

\begin{tabular}{c|l|c|c|c}
\hline $\begin{array}{c}\text { Hours } \\
\text { After } \\
\text { Birth }\end{array}$ & Mean & Range & SD & $\begin{array}{c}\text { No. of } \\
\text { Determi- } \\
\text { nations }\end{array}$ \\
\hline Cord & $19 \cdot 55$ & $11 \cdot 0-30 \cdot 0$ & $\pm 6 \cdot 8$ & 14 \\
1 & $16 \cdot 0$ & $11 \cdot 0-23 \cdot 0$ & $\pm 6 \cdot 0$ & 14 \\
2 & $15 \cdot 85$ & $10 \cdot 0-23 \cdot 0$ & $\pm 6 \cdot 1$ & 14 \\
3 & $15 \cdot 35$ & $12 \cdot 0-26 \cdot 0$ & $\pm 5 \cdot 0$ & 14 \\
5 & $14 \cdot 57$ & $11 \cdot 0-24 \cdot 0$ & $\pm 5 \cdot 6$ & 14 \\
7 & $14 \cdot 44$ & $11 \cdot 0-22 \cdot 0$ & $\pm 5 \cdot 0$ & 14 \\
9 & $14 \cdot 0$ & $10 \cdot 0-28 \cdot 0$ & $\pm 5 \cdot 4$ & 14 \\
11 & $14 \cdot 5$ & $10 \cdot 0-27 \cdot 0$ & $\pm 5 \cdot 0$ & 14 \\
18 & $14 \cdot 0$ & $10 \cdot 0-23 \cdot 0$ & $\pm 4 \cdot 4$ & 14 \\
24 & $14 \cdot 35$ & $10 \cdot 0-23 \cdot 0$ & $\pm 5 \cdot 8$ & 14 \\
36 & $14 \cdot 27$ & $9 \cdot 0-22 \cdot 0$ & $\pm 6 \cdot 0$ & 14 \\
48 & $13 \cdot 5$ & $7 \cdot 0-21 \cdot 0$ & $\pm 4 \cdot 7$ & 14 \\
\hline
\end{tabular}

infant's blood is adequately oxygenated the lactic acid level begins to fall, but the rate of fall is slower than occurs in the adult, and the adult level of lactic acid $(10 \mathrm{mg}$.) is not reached by all infants by the end of 2 days, though in the majority of infants it is.

The level of the lactic acid is an index of the oxygenation, as anaerobic metabolism produces lactic acid.

Cord values for lactic acid have been reported by Hendricks (1957) 24, and Kaiser and Goodlin (1958) $21 \cdot 6$, but no record of the lactic acid during the first 
48 hours has been found until Znamenáček and Přibylová (1964) who report values higher than ours.

Total Plasma Protein. The plasma protein level increases in the first hour (Table 9), due probably to loss of water from the plasma in the large calibre vein of the cord when compared with the plasma from the capillaries, as, with the changes of intravascular pressure in relation to tissue pressure caused by the alterations occurring at birth, the osmotic pressure of the plasma protein is insufficient to retain as much water as in utero. After this initial adjustment, the protein level is constant for the rest of the first 24 hours, but there is an increase in the second 24 hours, quite possibly due to the haemo-concentration seen in the sodium levels. The values reported show some variation: Denzer, Reiner, and Weiner (1939) 6.04, Rimington and Bickford (1947) 6.53, McMurray, Roe, and Sweet (1948) 6•0, Gairdner, Marks, Roscoe, and Brettell (1958) $6 \cdot 5$, Solomkin and Tauber (1959) $5 \cdot 7$, and Oliver et al. (1961) 6.4. Gairdner et al. reported a rise from 6.5 to 7.0 in 1 to 8 hours after birth, but Oliver et al. record a fall from $6 \cdot 4$ to $6 \cdot 1$ at the end of 1 hour. Graham, Wilson, Tsao, Baumann, and Brown (1951) record a steady fall from $6 \cdot 12$ at birth to 5.71 at 24 hours and Overman et al. a fall from $6 \cdot 3$ to $6 \cdot 1$ at 24 hours.

TABLE 9

TOTAL PROTEIN (PLASMA) CONCENTRATION (g./100 ml.) OF FULL-TERM NORMAL INFANTS (PRESENT SERIES)

\begin{tabular}{|c|c|c|c|c|}
\hline $\begin{array}{l}\text { Hours } \\
\text { After } \\
\text { Birth }\end{array}$ & Mean & Range & SD & $\begin{array}{c}\text { No. of } \\
\text { Determi- } \\
\text { nations }\end{array}$ \\
\hline $\begin{array}{c}\text { Cord } \\
1 \\
2 \\
3 \\
5 \\
7 \\
7 \\
9 \\
11 \\
18 \\
24 \\
36 \\
48\end{array}$ & $\begin{array}{l}6 \cdot 13 \\
6 \cdot 77 \\
6 \cdot 52 \\
6 \cdot 73 \\
6 \cdot 61 \\
6 \cdot 6 \\
6 \cdot 84 \\
6 \cdot 6 \\
6 \cdot 63 \\
6 \cdot 78 \\
6 \cdot 93 \\
7 \cdot 17\end{array}$ & $\begin{array}{l}4 \cdot 8-7 \cdot 3 \\
5 \cdot 8-8 \cdot 1 \\
5 \cdot 8-7 \cdot 9 \\
5 \cdot 7-8 \cdot 4 \\
5 \cdot 6-8 \cdot 5 \\
5 \cdot 5-7 \cdot 7 \\
5 \cdot 7-7 \cdot 9 \\
5 \cdot 6-8 \cdot 0 \\
5 \cdot 8-8 \cdot 2 \\
5 \cdot 9-7 \cdot 7 \\
5 \cdot 9-8 \cdot 2 \\
6 \cdot 0-8 \cdot 5\end{array}$ & $\begin{array}{l} \pm 0.67 \\
\pm 0.73 \\
\pm 0.56 \\
\pm 0.6 \\
\pm 0.63 \\
\pm 0.7 \\
\pm 0.56 \\
\pm 0.66 \\
\pm 0.68 \\
\pm 0.72 \\
\pm 0.73 \\
\pm 0.76\end{array}$ & $\begin{array}{r}10 \\
9 \\
6 \\
9 \\
9 \\
10 \\
6 \\
9 \\
9 \\
10 \\
10 \\
10\end{array}$ \\
\hline
\end{tabular}

Packed Cell Volume. This shows a short rise from cord to capillary at 1 hour and a slower rise up to 3 hours (Table 10). After this there is a steady fall, despite the haemo-concentration for the rest of the 48 hours (as mentioned above under Plasma Sodium).

As Gairdner et al. (1958) have shown, it is important to consider the size of the vessel from which the blood is taken. As a check, immediately after taking
TABLE 10

PACKED CELL VOLUME (\%) OF FULL-TERM NORMAL INFANTS (PRESENT SERIES)

\begin{tabular}{c|l|c|c|c}
\hline $\begin{array}{c}\text { Hours } \\
\text { After } \\
\text { Birth }\end{array}$ & Mean & Range & SD & $\begin{array}{c}\text { No. of } \\
\text { Determi- } \\
\text { nations }\end{array}$ \\
\hline Cord & $54 \cdot 17$ & $43 \cdot 0-62 \cdot 0$ & $\pm 6 \cdot 32$ & 12 \\
1 & $66 \cdot 0$ & $58 \cdot 0-77 \cdot 0$ & $\pm 7 \cdot 91$ & 13 \\
2 & $66 \cdot 25$ & $57 \cdot 0-76 \cdot 0$ & $\pm 7 \cdot 07$ & 10 \\
3 & $69 \cdot 9$ & $64 \cdot 0-82 \cdot 0$ & $\pm 8 \cdot 06$ & 12 \\
5 & $67 \cdot 0$ & $56 \cdot 0-75 \cdot 0$ & $\pm 8 \cdot 03$ & 13 \\
7 & $63 \cdot 1$ & $50 \cdot 0-76 \cdot 0$ & $\pm 7 \cdot 6$ & 13 \\
9 & $59 \cdot 34$ & $51 \cdot 0-68 \cdot 0$ & $\pm 6 \cdot 25$ & 10 \\
11 & $58 \cdot 5$ & $48 \cdot 0-70 \cdot 0$ & $\pm 7 \cdot 04$ & 13 \\
18 & $55 \cdot 29$ & $49 \cdot 0-61 \cdot 0$ & $\pm 6 \cdot 7$ & 13 \\
24 & $53 \cdot 09$ & $42 \cdot 0-64 \cdot 0$ & $\pm 6 \cdot 44$ & 13 \\
36 & $50 \cdot 94$ & $44 \cdot 0-56 \cdot 0$ & $\pm 6 \cdot 12$ & 13 \\
48 & $49 \cdot 18$ & $36 \cdot 0-59 \cdot 0$ & $\pm 5 \cdot 94$ & 13 \\
\hline
\end{tabular}

the cord blood at birth, capillary blood was collected from the heel in 3 babies. An interval of 5-10 minutes was inevitable between the time of collecting the two specimens, and the results of a full analysis are shown in Table 11 .

It will be seen that the PCV is higher in all 3

TABLE 11

COMPARISON OF SIMULTANEOUS DETERMINATIONS OF $\mathrm{K}, \mathrm{Na}, \mathrm{PCV}$, TOTAL PLASMA PROTEIN, PLASMA CALCIUM, PLASMA MAGNESIUM, BLOOD UREA, BLOOD SUGAR, BLOOD INORGANIC PHOSPHATE, AND BLOOD LACTIC BLOOD CONCENTRATIONS IN CORD BLOOD AND IN ACID: CONCENTRATIONS IN CORD BLOOD AND IN MINUTES AFTER BIRTH

\begin{tabular}{|c|c|c|c|}
\hline & $\begin{array}{l}\text { Infant } \\
\text { No. }\end{array}$ & $\begin{array}{c}\text { Cord } \\
\text { Blood }\end{array}$ & $\begin{array}{l}\text { Capillary } \\
\text { Blood }\end{array}$ \\
\hline Plasma potassium (mEq/l.) & $\begin{array}{l}1 \\
2 \\
3^{*}\end{array}$ & $\begin{array}{l}6 \cdot 1 \\
5 \cdot 5 \\
6 \cdot 1\end{array}$ & $\begin{array}{l}6 \cdot 2 \\
5 \cdot 5 \\
6 \cdot 1\end{array}$ \\
\hline Plasma sodium (mEq/l.) & $\begin{array}{l}1 \\
2 \\
3^{*}\end{array}$ & $\begin{array}{l}149.0 \\
151.0 \\
145.0\end{array}$ & $\begin{array}{l}149 \cdot 0 \\
150 \cdot 5 \\
145 \cdot 0\end{array}$ \\
\hline $\operatorname{PCV}(\%)$ & $\begin{array}{l}1 \\
2 \\
3\end{array}$ & $\begin{array}{l}58 \cdot 5 \\
56 \cdot 5 \\
56 \cdot 0\end{array}$ & $\begin{array}{l}69 \cdot 0 \\
64 \cdot 0 \\
63 \cdot 0\end{array}$ \\
\hline $\begin{array}{l}\text { Total plasma protein } \\
\text { (g./100 ml.) }\end{array}$ & $\begin{array}{l}1 \\
2 \\
3^{*}\end{array}$ & $\begin{array}{l}6 \cdot 3 \\
5 \cdot 85 \\
6 \cdot 75\end{array}$ & $\begin{array}{l}7 \cdot 2 \\
6 \cdot 7 \\
7 \cdot 35\end{array}$ \\
\hline Plasma calcium (mg./100 ml.) & $\begin{array}{l}1 \\
2 \\
3^{*}\end{array}$ & $\begin{array}{l}9 \cdot 4 \\
9 \cdot 55 \\
8 \cdot 4\end{array}$ & $\begin{array}{l}9 \cdot 3 \\
9 \cdot 6 \\
9 \cdot 1\end{array}$ \\
\hline $\begin{array}{l}\text { Plasma magnesium } \\
(\mathrm{mg} . / 100 \mathrm{ml} .)\end{array}$ & $\begin{array}{l}1 \\
2 \\
3^{*}\end{array}$ & $\begin{array}{l}1 \cdot 31 \\
1.7 \\
1 \cdot 8\end{array}$ & $\begin{array}{l}1 \cdot 53 \\
1.45 \\
2 \cdot 04\end{array}$ \\
\hline Blood urea (mg./100 ml.) & $\begin{array}{l}1 \\
2 \\
3^{*}\end{array}$ & $\begin{array}{l}33 \cdot 0 \\
38 \cdot 6 \\
31 \cdot 5\end{array}$ & $\begin{array}{l}32 \cdot 2 \\
40 \cdot 0 \\
74 \cdot 4\end{array}$ \\
\hline Blood sugar (mg./100 ml.) & $\begin{array}{l}1 \\
2 \\
3^{*}\end{array}$ & $\begin{array}{l}62 \cdot 0 \\
65 \cdot 0 \\
72 \cdot 0\end{array}$ & $\begin{array}{l}61 \cdot 0 \\
64 \cdot 0 \\
94 \cdot 0\end{array}$ \\
\hline $\begin{array}{l}\text { Blood inorganic phosphate } \\
\text { (mg./100 ml.) }\end{array}$ & $\begin{array}{l}1 \\
2 \\
3^{*}\end{array}$ & $\begin{array}{l}6 \cdot 5 \\
5 \cdot 3 \\
5 \cdot 3\end{array}$ & $\begin{array}{l}7 \cdot 3 \\
6 \cdot 2 \\
6 \cdot 7\end{array}$ \\
\hline $\begin{array}{l}\text { Blood lactic acid } \\
\text { (mg./100 ml.) }\end{array}$ & $\begin{array}{l}1 \\
2 \\
3^{*}\end{array}$ & $\begin{array}{l}22 \cdot 0 \\
28 \cdot 5 \\
42 \cdot 0\end{array}$ & $\begin{array}{l}37 \cdot 5 \\
42 \cdot 0 \\
51 \cdot 0\end{array}$ \\
\hline
\end{tabular}

* Delivered by forceps application. 
cases by an average amount of $8 \cdot 3 \%$, against an increase of $11.8 \%$ between the average values in the cord and the 1-hour specimen. Thus the majority of the increase is due to the smaller diameter of the vessel. The other fraction of the increase, reaching a maximum at 3 hours, is due in all probability to a transfer of plasma from the vascular system to the interstitial fluid, often clinically apparent in a slight puffiness of the extremities and occasionally actual pitting oedema.

TABLE 12

PLASMA CALCIUM CONCENTRATION (mg./100 ml.) OF FULL-TERM NORMAL INFANTS (PRESENT SERIES)

\begin{tabular}{c|c|c|c}
\hline $\begin{array}{c}\text { Hours } \\
\text { After } \\
\text { Birth }\end{array}$ & Mean & Range & $\begin{array}{c}\text { No. of } \\
\text { Determi- } \\
\text { nations }\end{array}$ \\
\hline Cord & $9 \cdot 34$ & $8 \cdot 2-11 \cdot 1$ & 5 \\
1 & $8 \cdot 95$ & $8 \cdot 1-9 \cdot 6$ & 4 \\
3 & $8 \cdot 92$ & $8 \cdot 0-9 \cdot 6$ & 5 \\
5 & $8 \cdot 38$ & $7 \cdot 3-9 \cdot 2$ & 5 \\
7 & $8 \cdot 32$ & $7 \cdot 1-10 \cdot 0$ & 5 \\
12 & $8 \cdot 22$ & $6 \cdot 9-10 \cdot 2$ & 5 \\
18 & $7 \cdot 84$ & $6 \cdot 9-9 \cdot 4$ & 5 \\
24 & $7 \cdot 7$ & $6 \cdot 2-9 \cdot 0$ & 5 \\
36 & $8 \cdot 02$ & $6 \cdot 1-9 \cdot 9$ & 5 \\
48 & $7 \cdot 94$ & $5 \cdot 9-9 \cdot 7$ & 5 \\
\hline
\end{tabular}

Serum Calcium. The technique used for estimation of calcium described by Wilkinson (1957) gives results averaging $0.8 \mathrm{mg}$. lower than the more usual oxalate method. There is a progressive fall of the calcium from birth till about 36 hours or occasionally longer (Table 12). This fall is not inversely connected with the level of phosphate as has been suggested, since for much of the time both fall together. It is more likely due to a temporary dysfunction of the parathyroids.

Values for calcium are given by Bakwin (1937) 11.0, Denzer et al. (1939) 11.53, Todd, Chuinard, and Wood (1939) 11 27, Bruck and Weintraub (1955) 10.59-all cord blood.

Bakwin records the level at intervals for the first 24 hours and finds a steady fall of $1.43 \mathrm{mg}$.

Denzer records results in the first and second days of life as $1.05 \mathrm{mg}$. less than his cord value. Todd also records a fall in the first 2 days of $1 \cdot 34 \mathrm{mg}$.

\section{Discussion}

This record of serial blood chemistry in infants is incomplete without the actual results for each age, but to record these either in tables or graphically would result in too unwieldy a paper. Those interested can consult the original thesis of P.T.A. in the University of London.

To appreciate the hourly variations, in Figs. 1 and 2 the means of all the estimations have been collected

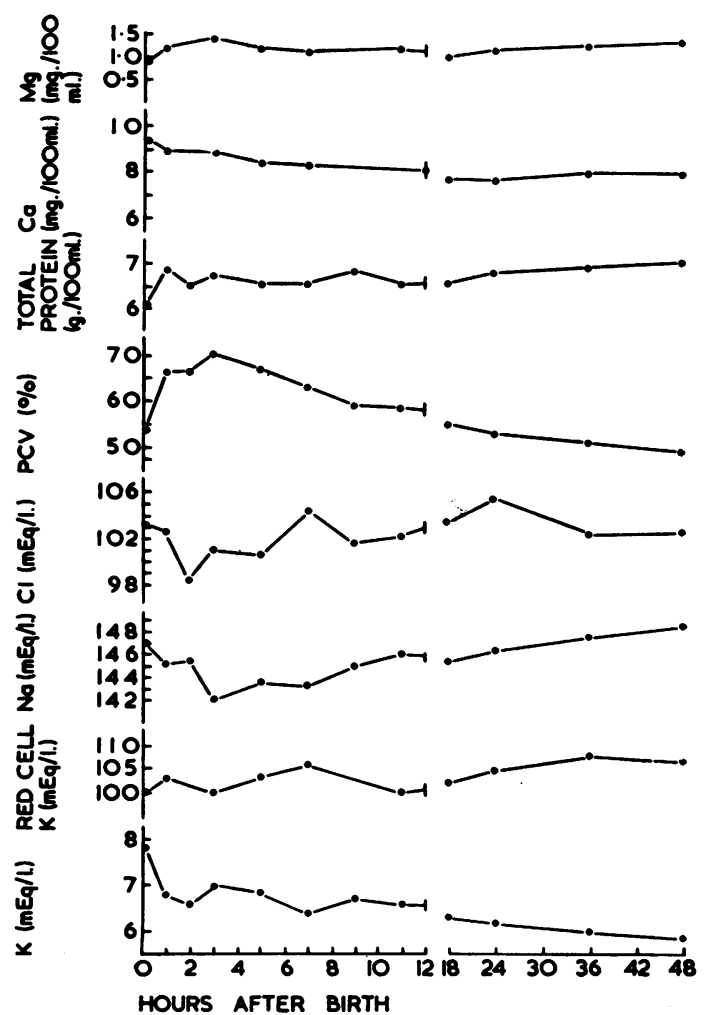

FIG. 1.-Mean values, over first 48 hours of life, of potassium, sodium, chloride, PCV, total protein, calcium, and magnesium.

together. In these infants the factor of a variable intake is absent, as the total intake in the first 48 hours was very low, so that the variations in the composition of the plasma should represent

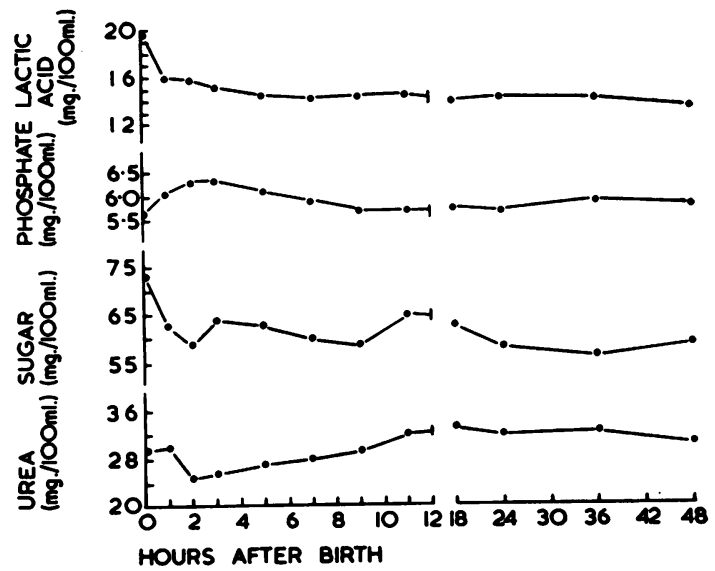

Fig. 2.-Mean values, over first 48 hours of life, of urea, sugar, inorganic phosphorus, and lactic acid. 
endogenous events occurring within the child, and an endeavour has been made to explain these in terms of known biochemical responses to the stimuli resulting from the events of birth and adaptation to independent existence. Not enough is known, however, to enable a clear picture of the causes of these changes to be made. In a subsequent paper, changes due to unphysiological situations will be reported.

\section{Summary}

The changes in the plasma sodium, potassium, chloride, phosphate, urea, sugar, lactic acid, calcium, total protein and packed cell volume during the first 48 hours of life have been reported and briefly discussed.

It is a pleasure to acknowledge the help given us by Professor J. H. Pinkerton, Dr. A. White Franklin, and Dr. A. P. Norman, and the ward sisters and staff, especially Sister Penrice and Sister Fairbrother, and to Dr. B. C. Mukerji for technical help. We are indebted to the Board of Governors of the Hospital for a grant enabling this work to be done, and to the M.R.C. for a personal grant to one of us (P.T.A.).

\section{REFERENCES}

Archer, H. E., and Robb, G. D. (1925). The tolerance of the body for urea in health and disease. Quart. J. Med., 18, 274.

Bakwin, H. (1937). Pathogenesis of tetany of the new-born. Amer. J. Dis. Childh., 54, 1211.

Barker, S. B., and Summerson, W. H. (1941). The colorimetric determination of lactic acid in biological material. J. biol. Chem., $138,535$.

Bruck, E., and Weintraub, D. H. (1955). Serum calcium and phosphorus in premature and full-term infants. Amer. J. Dis. Child., 90,653 .

Denzer, B. S., Reiner, M., and Weiner, S. B. (1939). Serum calcium in the newborn. Amer. J. Dis. Child., 57, 809.

Earle, D. P., Bakwin, H., and Hirsch, D. (1951). The plasma potassium level in the newborn. Proc. Soc. exp. Biol. (N.Y.), 76, 756.

Farquhar, J. W. (1954). Control of the blood sugar level in the neonatal period. Arch. Dis. Childh., 29, 519.

Gairdner, D., Marks, J., Roscoe, J. D., and Brettell, R. O. (1958). The fluid shift from the vascular compartment immediately after birth. ibid., 33, 489.

Giordano, C. (1963). Use of exogenous and endogenous urea for protein synthesis in normal and uremic subjects. J. Lab. clin. Med., 62, 231.

Graham, B. D., Wilson, J. L., Tsao, M. U., Baumann, M. L., and Brown, S. (1951). Development of neonatal electrolyte homeostasis. Pediatrics, $8,68$.

Hendricks, C. H. (1957). Studies on lactic acid metabolism in pregnancy and labor. Amer. J. Obstet. Gynec., 73, 492.
Houpt, T. R. (1963). Urea utilization by rabbits fed a low-protein ration. Amer. J. Physiol., 205, 1144.

James, L. S. (1960). Acidosis of the newborn and its relation to birth asphyxia. Acta paediat. (Uppsala), 49, Suppl. 122, 17.

Kaiser, I. H., and Goodlin, R. C. (1958). Alterations of pH, gases and hemoglobin in blood and electrolytes in plasma of fetuses of diabetic mothers. Pediatrics, 22, 1097.

McCance, R. A., and Widdowson, E. M. (1947). Blood-urea in the first nine days of life. Lancet, 1, 787.

- and - (1954). The influence of events during the last few days in utero on tissue destruction and renal function in the first two days of independent life. Arch. Dis. Childh., 29, 495.

- - and - (1955). Protein catabolism and renal function in the first two days of life in premature infants and multiple births. ibid., 30, 405.

McMurray, L. G., Roe, J. H., and Sweet, L. K. (1948). Plasma protein studies on normal newborn and premature infants. Amer. J. Dis. Child., 75, 265.

Natelson, S. (1957). Microtechniques of Clinical Chemistry: for the Routine Laboratory. Thomas, Springfield, Illinois.

Oberman, J. W., Gregory, K. O., Burke, F. G., Ross, S., and Rice, E. C. (1956). Electrophoretic analysis of serum proteins in infants and children. I. Normal values from birth to adolescence. New Engl. J. Med., 255, 743.

Oliver, T. K., Jr., Demis, J. A., and Bates, G. D. (1961). Serial blood-gas tensions and acid-base balance during the first hour of life in human infants. Acta paediat. (Uppsala), 50, 346.

Osterlund, K. (1955). A comparative investigation of the concentration of certain electrolytes in maternal and cord blood. Ann. Paediat. Fenn., Suppl. 4.

Overman, R. R., Etteldorf, J. N., Bass, A. C., and Horn, G. B. (1951). Plasma and erythrocyte chemistry of the normal infant from birth to two years of age. Pediatrics, 7, 565 .

Pederson, J. (1952). Diabetes and Pregnancy. Blood Sugar of Newborn Infants During Fasting and Glucose Administration. Danish Science Press, Copenhagen.

Pincus, J. G., Gittleman, I. F., Saito, M., and Sobel, A. E. (1956). A study of plasma values of sodium, potassium chloride, carbon dioxide, carbon dioxide tension, sugar, urea, the protein basebinding power, $\mathrm{pH}$, and haematocrit in prematures on the first day of life. Pediatrics, 18, 39.

Rimington, C., and Bickford, J. A. (1947). Pre- and post-natal development in immunity. Serum-albumin and serum-globulin levels in maternal and cord bloods of premature infants. Lancet, $1,781$.

Sanz, M. C. (1957). Ultramicro methods and standardization of equipment. Clin. Chem., 3, 406.

Smith, C. A. (1959). The Physiology of the Newborn Infant, 3rd ed. Thomas, Springfield, Illinois.

Solomkin, M., and Tauber, W. F. (1959). A study of constituents of the bloods of mother and infant at birth. Conn. Med., 23, 141.

Todd, W. R., Chuinard, E. G., and Wood, M. T. (1939). Blood calcium and phosphorus in the newborn. Amer. J. Dis. Child., $57,1278$.

Usher, R. (1959). The respiratory distress syndrome of prematurity. I. Changes in potassium in the serum and the electrocardiogram and effects of therapy. Pediatrics, 24, 562.

Widdowson, E. M., and McCance, R. A. (1956). The effect of development on the composition of the serum and extra-cellular fluids. Clin. Sci., 15, 361 .

Wilkinson, R. H. (1957). A micro-method for serum calcium and serum magnesium. J. clin. Path., 10, 126. (1960). Chemical Micromethods in Clinical Medicine. Charles C. Thomas, Springfield, Illinois.

Znamenáček, K., and Płribylová, H. (1964). Some parameters of respiratory metabolism in the first 3 days after birth. Acta paediat. (Uppsala), 53, 241. 